Article

\title{
Migration Rate Inhibition of Breast Cancer Cells Treated by Caffeic Acid and Caffeic Acid Phenethyl Ester: An In Vitro Comparison Study
}

\author{
Agata Kabała-Dzik ${ }^{1, *}$ (D), Anna Rzepecka-Stojko ${ }^{2}$, Robert Kubina ${ }^{1}$, Żaneta Jastrzębska-Stojko ${ }^{3}$, \\ Rafał Stojko ${ }^{4}$, Robert Dariusz Wojtyczka ${ }^{5}$ and Jerzy Stojko ${ }^{6}$ \\ 1 Department of Pathology, School of Pharmacy with the Division of Laboratory Medicine in Sosnowiec, \\ Medical University of Silesia in Katowice, Ostrogórska 30, 41-200 Sosnowiec, Poland; rkubina@sum.edu.pl \\ 2 Department of Pharmaceutical Chemistry, School of Pharmacy with the Division of Laboratory Medicine in \\ Sosnowiec, Medical University of Silesia in Katowice, Jagiellońska 4, 41-200 Sosnowiec, Poland; \\ annastojko@sum.edu.pl \\ 3 Department of Anesthesiology and Intensive Care, Prof. K. Gibiński University Clinical Center, \\ Medical University of Silesia in Katowice, Ceglana 35, 40-514 Katowice, Poland; zak@czkstojko.pl \\ 4 Department of Women Health, School of Health Sciences, Medical University of Silesia in Katowice, \\ Medyków 12, 40-752 Katowice, Poland; rstojko@sum.edu.pl \\ 5 Department and Institute of Microbiology and Virology, School of Pharmacy with the Division of Laboratory \\ Medicine in Sosnowiec, Medical University of Silesia in Katowice, Jagiellońska 4, 41-200 Sosnowiec, Poland; \\ rwojtyczka@sum.edu.pl \\ 6 Department of Toxicology and Bioanalysis, School of Pharmacy with the Division of Laboratory Medicine in \\ Sosnowiec, Medical University of Silesia in Katowice, Jagiellońska 4, 41-200 Sosnowiec, Poland; \\ jstojko@sum.edu.pl \\ * Correspondence: adzik@sum.edu.pl; Tel.: +48-32-364-13-54
}

Received: 19 September 2017; Accepted: 3 October 2017; Published: 19 October 2017

\begin{abstract}
One of the deadliest cancers among women is a breast cancer. Research has shown that two natural substances occurring in propolis, caffeic acid (CA) and caffeic acid phenethyl ester (CAPE), have significant anticancer effects. The purpose of our in vitro study was to compare cytotoxic activity and migration rate inhibition using CA and CAPE (doses of 50 and $100 \mu \mathrm{m}$ ) against triple-negative, MDA-MB-231 breast adenocarcinoma line cells, drawn from Caucasian women. Viability was measured by XTT-NR-SRB assay (Tetrazolium hydroxide-Neutral Red-Sulforhodamine B) for $24 \mathrm{~h}$ and $48 \mathrm{~h}$ periods. Cell migration for wound healing assay was taken for $0 \mathrm{~h}, 8 \mathrm{~h}, 16 \mathrm{~h}$, and $24 \mathrm{~h}$ periods. CAPE displayed more than two times higher cytotoxicity against MDA-MB-231 cells. $\mathrm{IC}_{50}$ values for the XTT assay were as follows: CA for $24 \mathrm{~h}$ and $48 \mathrm{~h}$ were $150.94 \mu \mathrm{M}$ and $108.42 \mu \mathrm{M}$, respectively, while CAPE was $68.82 \mu \mathrm{M}$ for $24 \mathrm{~h}$ and $55.79 \mu \mathrm{M}$ for $48 \mathrm{~h}$. For the NR assay: CA was $135.85 \mu \mathrm{M}$ at $24 \mathrm{~h}$ and $103.23 \mu \mathrm{M}$ at $48 \mathrm{~h}$, while CAPE was $64.04 \mu \mathrm{M}$ at $24 \mathrm{~h}$ and $53.25 \mu \mathrm{M}$ at $48 \mathrm{~h}$. For the SRB assay: CA at $24 \mathrm{~h}$ was $139.80 \mu \mathrm{M}$ and at $48 \mathrm{~h} 103.98 \mu \mathrm{M}$, while CAPE was $66.86 \mu \mathrm{M}$ at $24 \mathrm{~h}$ and $47.73 \mu \mathrm{M}$ at $48 \mathrm{~h}$. Both agents suspended the migration rate; however, CAPE displayed better activity. Notably, for the $100 \mu \mathrm{M}$ CAPE dose, motility of the tested breast carcinoma cells was halted.
\end{abstract}

Keywords: caffeic acid; CAPE; migration; wound healing; breast cancer; propolis

\section{Introduction}

Properly-fortified diets, especially those enriched with compounds such as polyphenols or phenolic acids, are found to counter the development of many diseases [1-3].

Propolis is one of many natural substances which are becoming increasingly popular for study by cancer research projects. Propolis is an amorphous, viscous substance, of a resin-like consistency, 
produced by honey bees (Apis mellifera) from collected plant pollen, which bees supplement with bee's wax or bee bread. The composition of propolis is extremely complex and varies depending on the locale, season, weather conditions, and plant species from which it is gathered [4-7].

Numerous scientific studies have shown that propolis has antiviral, antimicrobial, antifungal, and antiparasitic properties, as well as being known to have anti-inflammatory and antioxidant effects. Additionally, active, cardio-, and hepatoprotective effects have been measured using propolis. There are also research reports of propolis being used as a local anesthetic. Some authors report this compound has antitumor properties due to the antiproliferative, cytotoxic, and proapoptotic properties of propolis compounds. The high concentration of these substances in propolis determine its anti-inflammatory, anti-microbial, regenerative, immunomodulatory, hepatoprotective, antioxidative, and therefore antitumor activity [4-18].

There are hundreds of substances occurring in propolis. Two of these are caffeic acid (CA) and the caffeic acid phenethyl ester (CAPE). Some of their properties reported in research include: antioxidative, antibacterial, antiviral, anti-inflammatory, antiplatelet, antitumor, and antineoplastic effects [19-25].

In vitro research studies have clearly shown the cytotoxic properties of CAPE against: cells of pulmonary carcinoma, gastric carcinoma, colorectal carcinoma, malignant melanoma, hepatic carcinoma, pancreatic carcinoma, as well as cervical carcinoma [26-33].

Our earlier research showed that CA inhibits the viability and migration process of oral carcinoma SCC-25 cells and head and neck squamous carcinoma cells, while CAPE was directly reported as a growth inhibitor of breast cancer cells [34,35].

CAPE's antitumor activity was also reported. CAPE inhibits activity of cancer cells by using the significant nuclear transcription factor NF- $\mathrm{KB}$. NF- $\mathrm{kB}$ inhibits apoptosis, induces proliferation, and intensifies angiogenesis. Evidence shows that NF- $\mathrm{kB}$ could be one of the most important factors in the process of oncogenesis and cancer progression. Moreover, it was shown that CAPE aggregates the Fas death-inducing receptors through a Fas-L-independent mechanism [36-38].

Research studies of breast cancer have shown CAPE is an inhibitor of FGF-2 (fibroblasts growth factor type 2), which is a factor of tumor growth. CAPE performance was evaluated positively, both for in vitro and in vivo research of MCF-7 and MDA-231 breast cancer cells. It is worth noting that CAPE did not affect healthy cells [23,39]. It was also shown that CAPE reduces expression of the mdr-1 gene, which causes increased sensitivity of tumor cells to chemotherapy. Also, after treatment with CAPE, the decreased vascular endothelial growth factor (VEGF) inhibited angiogenesis and tumor growth $[40,41]$.

Breast cancer is one of the deadliest cancers among women. It is well known that genetic changes are conducive to the development of cancer. For instance, activation of oncogenes and alteration of tumor suppressor gene pathways leads to the development of tumor cells. Eventually, tumor cells lose complete control from highly regulated cell growth signals, leading to abnormal proliferation and avoiding apoptosis [42].

Breast cancer is a heterogeneous disease with many biological subtypes. One is triple negative breast cancer (TNBC). TNBC is much more aggressive than breast cancer of other molecular subtypes and known for its frequency of recurrence. As a result, the mortality rate of patients with TNBC is significantly higher than among patients with other types of breast cancer (estrogen receptor $\alpha$ and progesterone receptor positive) [43].

The treatment of a triple negative breast carcinoma depends on the severity of the disease. The choice of therapy is affected by the presence of metastases, the size of the primary tumor, and the result of detailed pathological tests, such as the degree of malignancy of the tumor, which determines the rate of division of tumor cells. Surgical methods, radiotherapy, and chemotherapy are used in the treatment of triple negative breast cancer. In the treatment of patients with TNBC, it is important to inhibit a formation of blood vessels providing nutrients to tumor tissues, the angiogenesis. However, the therapeutic options are very small here, but neither hormone therapy nor HER2 drugs works. 
Therefore, the average survival time in this group is still less than in patients with other types of breast cancer. The biological characterization of the tumor cell is the method used to determine the type of tumor and to obtain valuable information on the factors influencing its growth. Triple negative breast cancer is diagnosed in patients under the age of 50. Factors that promote TNBC are: early menopause, obesity at menopausal age, and breast cancer in the family. The disease is characterized by an aggressive course, rapid tumor growth, and rapid onset of distal metastases (especially to the brain and lungs, and to a lesser extent bone and liver) and early relapse (within 1-3 years of diagnosis). A large number of patients with this type of cancer have a poor prognosis due to low remission during adjuvant therapy, and in the case of metastases a short survival time and high resistance to chemotherapy [44-48].

The response rate among patients with metastatic breast cancer is gradually decreasing, possibly due to the tumor's resistance to a wide range of cancer therapies [43,49-51]. Unfortunately, it must be mentioned that metastatic breast cancer's resistance to all forms of systemic treatments (hormonal, chemotherapy, and targeted) results in an estimated $90 \%$ or more of patients with metastatic disease developing tumors which will prove lethal [52].

The aims of decreasing toxicity levels of standard breast cancer treatment and increasing patients' survival chances have led researchers to test natural substances and their varying compounds. Such studies have yielded highly positive and encouraging results for breast cancer treatment. Taking into consideration the above facts, we compare in vitro effects of CAPE and CA (viability and migration) on MDA-MB-231 human breast cancer cells, which to the best of our knowledge is a new approach.

\section{Materials and Methods}

\subsection{Cell Lines and Reagents}

\subsubsection{Breast Cancer Cell Line MDA-MB-231}

In this research, the MDA-MB-231 line (human breast adenocarcinoma TNBC, No. 92020424 SIGMA from Sigma-Aldrich, Poznań, Poland) was used, as it is a model of human triple-negative breast cancer. The manufacturer's recommendations for preparations were all carefully followed. The MDA-MB-231 cells were cultured with Leibovitz's L-15 medium, with $10 \%$ of inactivated fetal bovine serum (FBS, Sigma-Aldrich, Poznań, Poland), and kept at $37^{\circ} \mathrm{C}$, without $\mathrm{CO}_{2}$.

All cultured cells were supplemented with antibiotics of the following concentrations: penicillin-100 U.mL $\mathrm{m}^{-1}$, streptomycin-100 $\mu \mathrm{g} \cdot \mathrm{mL}^{-1}$ and fungistatic amphotericin B with a concentration of $0.25 \mu \mathrm{g} \cdot \mathrm{mL}^{-1}$. The medium was changed every 2-3 days, with the passage carried out with a confluence of $80 \%$ to $90 \%$.

\subsubsection{CA and CAPE}

Both caffeic acid (CA, Sigma: C0625) and caffeic acid phenethyl ester (CAPE, Sigma: C8221) were purchased from Sigma-Aldrich, Poznan, Poland and were collected, stored, and used specifically according to the manufacturer's instructions.

\subsection{Microscopic Evaluation of Carcinoma Cells Morphology. Hematoxylin and Eosin Staining Protocol}

Initially, the MDA-MB-231 cells were inoculated into 2-chamber microscopic culture vessels (Lab-Tek, Waltham, MA, USA) at a count of 1000 cells/well. Depending on the time of the experiment, we added proper concentrations of the studied compounds to the media and left them for 24 and $48 \mathrm{~h}$. This was followed by leaving the cultures for $24 \mathrm{~h}$ to obtain the cells' growth rate. They were then fixed for $12 \mathrm{~h}$ in $96 \%$ ethanol. The cells were then hydrated in the following series of dilutions: $99.6 \%, 96 \%$, $90 \%, 80 \%, 70 \%$, and $50 \%$ and stained with hematoxylin for $7 \mathrm{~min}$ (standard H\&E staining protocol). Next, the plates were washed with PBS solution for approximately $30 \mathrm{~min}$ to blue up and were then incubated for $30 \mathrm{~s}$ with eosin. PBS solution was used again to wash the plates, and they were then 
dehydrated with ethanol of increasing concentrations of $50 \%, 70 \%, 80 \%, 90 \%, 96 \%$, and $99.6 \%$. Finally, the plates were immersed in the ethanol and xylene mixture (50:50) for $1 \mathrm{~min}$ and then in pure xylene. The plates were then mounted and analyzed under a microscope.

\subsection{Cell Viability by Mitochondrial Activity, XTT Test Assay}

Viable cells depend on an intact mitochondrial respiratory chain and an intact mitochondrial membrane. Activity of the measured compounds was determined using mitochondrial dehydrogenases from the viable cells. XTT (2,3-bis[2methoxy-4-nitro-5-sulfopheny]-2H-tetrazolium -5-carboxyanilide inner salt) is a tetrazolium salt that cleaves to formazan by the succinate dehydrogenase system, which belongs to the mitochondrial respiratory chain. This is significant, as it is only active in viable cells. Mitochondrial succinate dehydrogenase reduces yellow tetrazolium salt into a soluble orange formazan in the presence of an electron coupling reagent. The number of originating formazan is proportional to the amount of living cells [53]. We measured the enzyme activity at $480 \mathrm{~nm}$, which is in line with the manufacturer's recommendation. The XTT assay was obtained from Xenometrix AG, Allschwil, Switzerland.

To measure cytotoxicity, the cells were inoculated on 96-well plates, at an amount of $10^{4}$ cells/well. A fresh medium was added and left for $72 \mathrm{~h}$ to obtain the rate of cell growth. After the medium was decanted, separate culture mediums were added which contained $50 \mu \mathrm{M}$ and $100 \mu \mathrm{M}$ of either CA or CAPE, which had been prepared during a series of dilutions in the culture medium. A measure of $0.1 \mathrm{~mL}$ of medium with the defined concentrations of the substances was added to each well and left for $24 \mathrm{~h} / 48 \mathrm{~h}$ in a $\mathrm{CO}_{2}$ incubator at $37^{\circ} \mathrm{C}$. The test procedure was performed exactly in accordance with the instructions and protocol of the manufacturer.

\subsection{Cytotoxicity by Lyzosomal Activity, NR Test Assay}

Cell survival and viability can also be measured by using the ability of viable cells to incorporate and bind to neutral red (NR), which is best performed on adherent cells. Neutral red is a weak cationic dye that readily penetrates the cell membrane and accumulates intracellularly in lysosomes (lysosomal $\mathrm{pH}<$ cytoplasmic $\mathrm{pH}$ ), where it binds to anionic sites of the lysosomal matrix. Lysosomal fragility and other effects, which gradually became irreversible, are caused by changes of the cell surface and the sensitivity of the lysosomal membrane. Such alterations, induced by the action of xenobiotics, result in decreased uptake and binding of NR. Therefore, it is possible to distinguish between viable, damaged, or dead cells [54]. The NR test was obtained from Xenometrix AG, Allschwil, Switzerland. We used CA and CAPE at concentrations of $50 \mu \mathrm{M}$ and $100 \mu \mathrm{M}$, with $24 \mathrm{~h}$ and $48 \mathrm{~h}$ of incubation. The quantity of dye incorporated into cells was measured by spectrometry at $540 \mathrm{~nm}$, which is directly proportional to the number of cells of the intact membrane. Test procedures were performed exactly following the instructions and protocol of the manufacturer.

\subsection{Cell Proliferation by SRB Test Assay}

Cell proliferation, measured as total protein synthesis, is a very sensitive toxicology marker. Sulforhodamine B (SRB, Acid Red 52) is an anionic dye that binds electrostatically to cellular proteins. SRB binds stoichiometrically to cellular proteins (when mild acidic conditions are guaranteed) and can then be extracted under basic conditions. The total amount of bound dye can be used as a proxy for cell mass, which is directly proportional to cell proliferation [55,56]. A fixed dye was solubilized and measured photometrically at OD $540 \mathrm{~nm}$, with a reference filter of $690 \mathrm{~nm}$. The OD values were correlated with total protein content and therefore with cell number. Concentrations of CA and CAPE of $50 \mu \mathrm{M}$ and $100 \mu \mathrm{M}$ were used to make the experiments for $24 \mathrm{~h}$ and $48 \mathrm{~h}$ of incubation. The SRB test was obtained from Xenometrix AG, Allschwil, Switzerland. Procedure of the test was performed exactly in accordance to the instructions and protocol of the manufacturer. 


\subsection{Migration-Cell Wound Closure Assay}

Carcinoma cell migration is the result of variable biological processes, with a specific characteristic seen in their coordination. Wound-healing assays are standard and commonly used methods for investigation of cell migration. CA's and CAPE's ability to modify cell motility using the scratch wound healing assay was then analyzed $[57,58]$. This method was implemented to evaluate the migration activity rate of MDA-MB-231 cells exposed to CA and CAPE.

Briefly, the MDA-MB-231 cells $\left(4 \times 10^{6}\right.$ cells/well $)$ were plated in 6-well plates for $48 \mathrm{~h}$ to a confluence of about $80 \%$, then wounded by scratching with a p200 pipette tip. Thereafter, the debris was removed and we washed the cells once with $1 \mathrm{~mL}$ of the growth medium to assure the edges of the scratch were smoothed by washing. We took utmost care to make the wounds of the same dimensions, both for the experimental and control cells to minimize any possible variety resulting from a difference in scratch width.

The cells were then incubated with DMEM medium containing $0.5 \%$ FBS and treated with CA/CAPE doses of $50 \mu \mathrm{M}$ and $100 \mu \mathrm{M}$, respectively. The control sample contained the cells and a standard medium without any active agents. The MDA-MB-231 cell migration was assessed by monolayer gap closure migration assay, embedded by free ImageJ software (version 1.50i, National Institute of Health, Bethesda, MD, USA), with a wound healing tool macro (Montpellier RIO Imaging, CNRS, Montpellier, France). The area of the initial wound was measured, followed by gap area measurements after $8 \mathrm{~h}, 16 \mathrm{~h}$, and $24 \mathrm{~h}$. The migration factor was presented as the gap area value over the initial scratch area.

\subsection{Statistical Analysis}

All results are expressed as means \pm SD and were obtained from three separate experiments and performed in quadruplicates $(n=12)$. The results were performed with independent sample $t$-tests. The experimental means were compared to the means of untreated cells harvested in a parallel manner. Differences between $24 \mathrm{~h} / 48 \mathrm{~h}$ and control samples were tested for significance using the one- and multiple-way Friedman ANOVA test. A $p$-value less than 0.05 was considered statistically significant.

\section{Results}

To obtain the quantitative assessment of breast cancer cells' viability, the XTT-NR-SRB (Tetrazolium hydroxide-Neutral Red-Sulforhodamine B) assay was used. IN a parallel fashion, the effects of selected times/concentrations of CA and CAPE on breast cancer cell motility and migration were evaluated. Figure 1 shows MDA-MB-231 carcinoma cells' morphology features as well as the impact of CA and CAPE on these cells. Examined cells were as phenotypical as the spindle shaped cells, with a visible hyperchromasia. Cell nuclei shapes were irregular. Small cells clustered around the large ones. The large, irregular nuclei contained several nucleoli in the nucleus. A pleomorphism of size and shape, as well as a coloration of nuclei, were visible. In the optical microscope, morphological characteristics of the apoptotic cells were visible, after the CA and CAPE treatment. Namely, we observed a cytoplasm density and changes in nuclear chromatin. The cytoplasmic shapes were changed. A fragmentation of a cytoplasm was visible. The cells were separated from each other.

For years, tetrazolium salts have been widely used as detection reagents in histochemical localization studies and cell biology assays. Like the MTT assay (reducing tetrazolium dye: 3-(4,5-dimethylthiazol-2-yl)-2,5-diphenyltetrazolium bromide to formazan), XTT measures cell viability based on the activity of enzymes in mitochondria of live cells, which reduces XTT and becomes inactive shortly after cell death. The data obtained in the experiment were normalized and presented as the percentage of control values (Figure 2).

When CA was used for treatment of MDA-MB-231, cell viability decreased as the dose increased, dropping from $93.1 \%$ for a dose of $10 \mu \mathrm{M}, 89.8 \%$ for $25 \mu \mathrm{M}, 77.9 \%$ for $50 \mu \mathrm{M}$, and a value of $66.4 \%$ 
was reached with a dose of $100 \mu \mathrm{M}$ after $24 \mathrm{~h}$ (Figure 2a,d). Simultaneously, when CAPE activity was compared to that of CA against MDA-MB-231 cells (Figure 2a,d), CAPE cell viability values for a dose of $10 \mu \mathrm{M}$ were similar to CA (at $24 \mathrm{~h}$, CA was $93.1 \%$, while CAPE was $92.4 \%$; after $48 \mathrm{~h}$, CA was $92.4 \%$ and CAPE was $90.4 \%$ ). The smallest doses of these two polyphenols had a similar cytotoxic effect on the examined cells. The effect increased in a dose-dependent manner for both agents. For CAPE, the values reached $68.4 \%, 51.9 \%$, and $37.5 \%$ for respective doses of 25,50 , and $100 \mu \mathrm{M}$ (Figure $2 \mathrm{a}, \mathrm{c}$ ), meaning that a stronger cytotoxic effect was achieved with CAPE at $24 \mathrm{~h}$. After $48 \mathrm{~h}$ of incubation (Figure 2b), for both CAPE and CA, cell viability showed a dose-dependent effect and the values were as follows: for a $10 \mu \mathrm{M}$ dose CAPE was $90.4 \%$ and CA $92.4 \%$, for a dose of $25 \mu \mathrm{M}$ CAPE was $53.5 \%$ and CA $79.5 \%$, for $50 \mu \mathrm{M}$ CAPE was $45.3 \%$ and CA $68.5 \%$, and finally, for $100 \mu \mathrm{M}$ CAPE was $31.6 \%$ and CA $55.5 \%$.

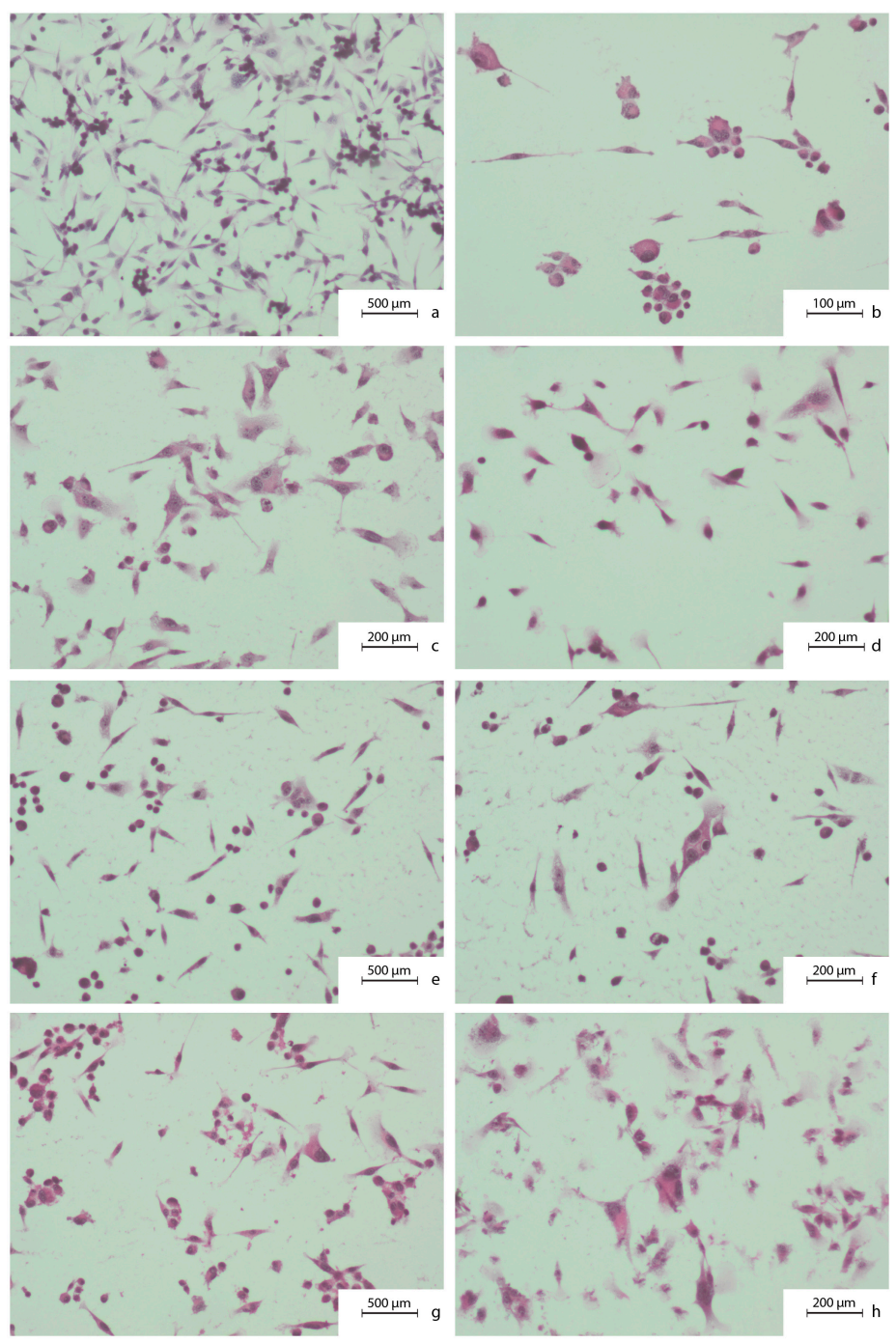

Figure 1. Cytomorphological view of MDA-MB-231 breast cancer cells without any treatment (a-d) as well as after $24 \mathrm{~h}$ of caffeic acid (CA) (e,f) and $24 \mathrm{~h}$ of caffeic acid phenethyl ester (CAPE) treatment (g,h), both with a $50 \mu \mathrm{M}$ dose. To prepare the samples a hematoxylin and eosin staining was used. Exposition: optical magnification $\times 100(\mathbf{a}, \mathbf{e}, \mathbf{g}), \times 400(\mathbf{c}, \mathbf{d}, \mathbf{f}, \mathbf{h}), \times 600(\mathbf{b})$. Main features: (a) phenotypically as spindle-shaped cells (caudate, tadpole), hyperchromasia; (b) irregular nuclear shapes, small clusters of cells around the large ones; (c) large nuclei with irregular shape and several nucleoli in the nucleus; (d) pleomorphism of size, shape, and coloration of nuclei and whole cells; (e) karyopyknosis; (f) lower cell-cell contact; (g) karyopyknosis, cytoplasm density; (h) cytoplasm density and a shape change, cytoplasm fragmentation. 
Comparing CAPE activity to that of CA, viability was again lower for CAPE at the same dosage after $48 \mathrm{~h}$. This showed a dependent trend for the dose and time domain (smaller impact) for both examined substances (Figure 2c,d).



Figure 2. Cytotoxic effects of caffeic acid phenethyl ester (CAPE) and caffeic acid (CA) were both tested using concentrations of from 10 to $100 \mu \mathrm{M}$ with $24 \mathrm{~h}$ and $48 \mathrm{~h}$ incubation times on the breast cancer cell line MDA-MB-231 using XTT (2,3-bis[2methoxy-4-nitro-5-sulfopheny]-2H-tetrazolium-5-carboxyanilide inner salt) Cell Proliferation Assay. Both polyphenols caused visible dose-dependent effects. Stronger activity was observed for CAPE than CA starting with a dose of $25 \mu \mathrm{M}$ of each agent following $24 \mathrm{~h} \mathrm{(a)}$ and $48 \mathrm{~h} \mathrm{(b)} \mathrm{incubation} \mathrm{times.} \mathrm{A} \mathrm{CAPE} \mathrm{treatment} \mathrm{of} 48 \mathrm{~h}$ gave slightly stronger cytotoxic effect compared to $24 \mathrm{~h}$ (except a $10 \mu \mathrm{M}$ dose) and was exclusively stronger for the $25 \mu \mathrm{M}$ dose (c); however, succeeding dose increases of CAPE (50 and $100 \mu \mathrm{M})$ didn't yield symptomatic difference in viability, with both times reaching a low level. The experiment times $(\mathbf{c}, \mathbf{d})$ had only a small impact on cytotoxic activity. The results were presented as a mean and standard deviation of three independent experiments, with 12 wells each $\left(p<0.05\right.$; Friedman ANOVA test; ${ }^{*}$ - significant difference vs. control, \#-significant difference $48 \mathrm{~h}$ vs. $24 \mathrm{~h}$ ).

The key component of the next viability test performed was the vital dye, neutral red (NR). Viable cells take up the dye by active transport and incorporate the dye into lysosomes, whereas non-viable cells do not take up the dye. The data obtained in the experiment were normalized and presented as \% of viability over controls (Figure 3).

Using CA against MDA-MB-231 cells, the cell mortality increased in a dose-dependent manner. The viability values dropped from $93.26 \%$ for a dose of $10 \mu \mathrm{M}$, to $89.56 \%$ for $25 \mu \mathrm{M}, 71.39 \%$ for $50 \mu \mathrm{M}$, and $64.54 \%$ with a dose of $100 \mu \mathrm{M}$ of CA after $24 \mathrm{~h}$ (Figure 3a,d). Comparing CAPE's cytotoxic activity to that of CA against MDA-MB-231 cells (Figure 3a,b), cell viability values for a dose of $10 \mu \mathrm{M}$ were similar: at 24 h CA was $93.26 \%$ and CAPE was $91.96 \%$, while at 48 h CA was $91.08 \%$ and CAPE $90.36 \%$. A dosage of $10 \mu \mathrm{M}$ of both polyphenols had a similar cytotoxic effect on the examined cells (independent of time). Using CAPE against the examined cells, at $24 \mathrm{~h}$ the values reached $66.30 \%$, 
$47.40 \%$, and $35.12 \%$ for doses of 25,50 , and $100 \mu \mathrm{M}$, respectively (Figure $3 \mathrm{a}, \mathrm{c}$ ). The results sustain that CAPE achieved a stronger cytotoxic effect at $24 \mathrm{~h}$.

For both substances, cell viability manifested a dose-dependent effect after $48 \mathrm{~h}$ of incubation (Figure $3 b$ ). The values were: at $10 \mu \mathrm{M}$ CAPE was $90.36 \%$ and CA $91.08 \%$, at $25 \mu \mathrm{M} \mathrm{CAPE}$ was $55.02 \%$ and CA $78.25 \%$, for $50 \mu \mathrm{M}$ CAPE was $41.38 \%$ and CA $65.80 \%$, and finally, for $100 \mu \mathrm{M}$, CAPE was $29.46 \%$ and CA: $53.86 \%$. Therefore, CAPE induces greater cell mortality than CA at the same dosage. Both CA and CAPE showed a dependent trend for the dose and time domain, but again a smaller impact (Figure 3c,d).

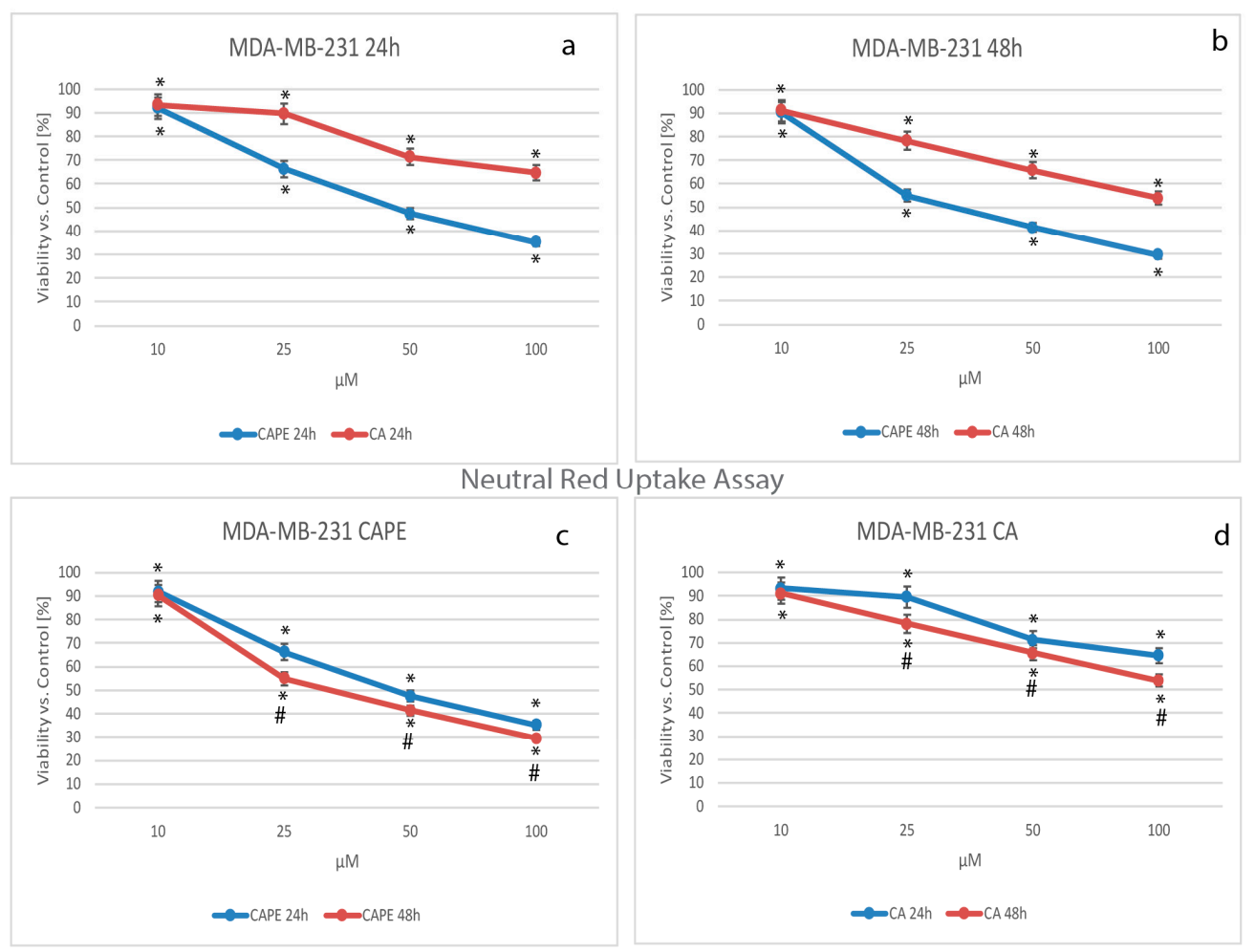

Figure 3. Cytotoxic effects of caffeic acid phenethyl ester (CAPE) and caffeic acid (CA) were tested using concentrations of from 10 to $100 \mu \mathrm{M}$ with $24 \mathrm{~h}$ and $48 \mathrm{~h}$ incubation times on the breast cancer cell line MDA-MB-231 using neutral red (NR) Assay. Both polyphenols caused visible dose-dependent effects. A higher mortality factor was observed with CAPE than CA, starting from a dose of $25 \mu \mathrm{M}$ of the tested compounds $(\mathbf{a}, \mathbf{b})$ for both $24 \mathrm{~h}$ and $48 \mathrm{~h}$ periods. In (c), using a dose of $10 \mu \mathrm{M}$ of CAPE, the $48 \mathrm{~h}$ experiment did not produce any significant cytotoxic effects when compared to $24 \mathrm{~h}$; nevertheless, a conspicuously stronger effect for $25 \mu \mathrm{M}$ was observed. The succeeding dosage increases of CAPE (50 and $100 \mu \mathrm{M}$ ) displayed only a slight difference in viability factor, with both reaching a very low level. The cytotoxic activity of both substances showed no spectacular difference over time (c,d). The results were presented as mean and standard deviation of three independent experiments, with 12 wells each $(p<0.05$; Friedman ANOVA test; *-significant difference vs. control, \#-significant difference $48 \mathrm{~h}$ vs. $24 \mathrm{~h})$.

The key component of the last cytotoxicity test performed was the dye, Sulforhodamine B (Acid Red 52). An increase or decrease in the number of cells causes an associated change in the amount of dye incorporated by the cells in the culture. This indicates the specific degree of cytotoxicity caused by the test material. Data received during the experiment were normalized and presented as \% of viability over controls (Figure 4).

Testing CA against MDA-MB-231 cells, cell viability declined in a dose-dependent manner, falling after $24 \mathrm{~h}$ from $93.13 \%$ for a dose of $10 \mu \mathrm{M}$, to $92.78 \%$ for $25 \mu \mathrm{M}, 67.46 \%$ for $50 \mu \mathrm{M}$, and to a value 
of $66.89 \%$ using a dose of $100 \mu \mathrm{M}$ CA (Figure $4 \mathrm{a}, \mathrm{d}$ ). When CAPE cytotoxic activity was compared to CA against MDA-MB-231 cells (Figure $4 \mathrm{a}, \mathrm{b}$ ), cell viability values for a dose of $10 \mu \mathrm{M}$ were again close to those of CA. At $24 \mathrm{~h}$, CA was $93.19 \%$ and CAPE $92.21 \%$, and at $48 \mathrm{~h}$, CA was $91.99 \%$ while CAPE was $86.90 \%$ (where a slight difference was finally observed). At a dosage of $10 \mu \mathrm{M}$, both polyphenols had a similar cytotoxic effect on the examined cells, which was also observed in viability tests performed earlier for this study. The viability was dependent for the dose and time domain. For CAPE at $24 \mathrm{~h}$, the values reached $68.85 \%, 50.05 \%$, and $36.13 \%$ for doses of 25,50 , and $100 \mu \mathrm{M}$, respectively (Figure 4a,c). Again, CAPE's stronger cytotoxic effect than CA's was confirmed after $24 \mathrm{~h}$.

After $48 \mathrm{~h}$ of incubation (Figure $4 \mathrm{~b}$ ) for both CAPE and CA, cell viability revealed a dose-dependent effect, with values as follows: for $10 \mu \mathrm{M}$ CAPE was $86.90 \%$ and CA $91.99 \%$, for $25 \mu \mathrm{M}$ CAPE was $56.08 \%$ and CA $77.69 \%$, for $50 \mu \mathrm{M}$ CAPE was $37.80 \%$ and CA $64.22 \%$, and finally, $100 \mu \mathrm{M}$ CAPE reached $22.98 \%$ and CA $54.88 \%$. Comparing CAPE to CA after $48 \mathrm{~h}$, cell mortality was again higher for CAPE than CA at the same dosage. Dependent trends in the dose and time domain (greater impact than by XTT and NR) for both CA and CAPE were confirmed (Figure 4c,d).

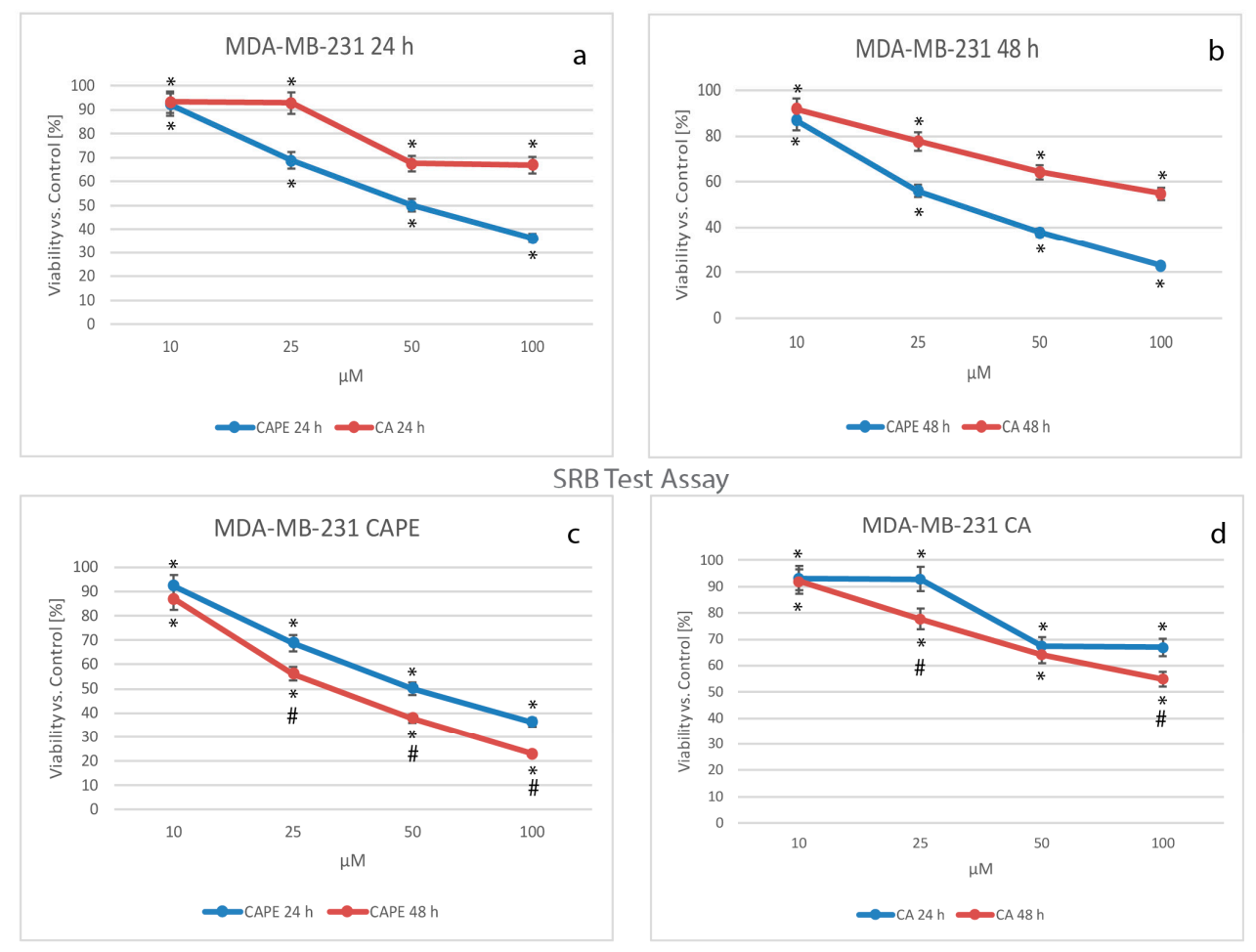

Figure 4. Viability results of the SRB (Sulforhodamine B) assay of caffeic acid phenethyl ester (CAPE) and caffeic acid (CA) at concentrations of from 10 to $100 \mu \mathrm{M}$ for $24 \mathrm{~h}$ and $48 \mathrm{~h}$ incubation times on the breast cancer cell line MDA-MB-231. Like the XTT (2,3-bis[2methoxy-4-nitro-5-sulfopheny]-2H-tetrazolium-5-carboxyanilide inner salt) and NR (neutral red) tests, there was a visible dose-dependent effect for both polyphenols. Interestingly, for the $24 \mathrm{~h}$ experiment, CA (a) expressed 'two levels' —a first for 10 and $25 \mu \mathrm{M}$ and a second (d), for 50 and $100 \mu \mathrm{M}$; this phenomenon could be explained by nonlinear absorbance; however, within a $48 \mathrm{~h}$ experiment it does not exist. Greater cancer cell mortality using CAPE rather than CA started again (just as with XTT and NR) from a dose of $25 \mu \mathrm{M}$ of each tested compound for both $24 \mathrm{~h}$ (a) and $48 \mathrm{~h}$ (b) incubation times. After $48 \mathrm{~h}$ (c), CAPE treatment showed a stronger cytotoxic effect in comparison to the $24 \mathrm{~h}$ period (except the $10 \mu \mathrm{M}$ dose). The experiment time had only slight impact on the cytotoxic activity of the tested compounds (c,d), which wasn't in opposition to the XTT and NR test assay. The results were presented as mean and standard deviation of three independent experiments 12 wells each $(p<0.05$; Friedman ANOVA test; * - significant difference vs. control, \#—significant difference 48 h vs. 24 h). 
For both substances (CA and CAPE) used for the MDA-MB-231 breast cancer line, the half maximal inhibitory concentration $\left(\mathrm{IC}_{50}\right)$ was calculated by all three methods during the experiment. It is significant that the $50 \%$-mortality of breast cancer cells (MDA-MB-231) were ca. twice as low for CAPE than CA for all methods. This showed that CAPE has a stronger cytotoxic effect on MDA-MB-231 cells than CA during $24 \mathrm{~h}$ and $48 \mathrm{~h}$ experiments. The $\mathrm{IC}_{50}$ results are shown in Table 1.

Table 1. $\mathrm{IC}_{50}(\mu \mathrm{M})$ values of caffeic acid (CA) and caffeic acid phenethyl ester (CAPE) in relation to breast cancer MDA-MB-231 for $24 \mathrm{~h}$ and $48 \mathrm{~h}$, using different methods (XTT, NR, SRB, respectively: 2,3-bis[2methoxy-4-nitro-5-sulfopheny]-2H-tetrazolium-5-carboxyanilide inner salt, neutral red, Sulforhodamine B). All data demonstrated that lower doses of CAPE (ca. twice as low as CA) are needed to receive a similar mortality effect on MDA-MB-231 cells.

\begin{tabular}{cccc}
\hline \multirow{2}{*}{ Method } & Compound & $\begin{array}{c}\text { Time of Incubation } \\
\mathbf{2 4} \mathbf{~ h}\end{array}$ & $\begin{array}{c}\text { Time of Incubation } \\
\mathbf{4 8 ~ h}\end{array}$ \\
\hline \multirow{2}{*}{ XTT } & CA & 150.94 & 108.42 \\
& CAPE & 68.82 & 55.79 \\
NR & CA & 135.85 & 103.23 \\
& CAPE & 64.04 & 53.25 \\
SRB & CA & 139.80 & 103.98 \\
& CAPE & 66.86 & 47.73 \\
\hline
\end{tabular}

Considering the cytotoxic effect of CA and CAPE (measured in this study by three methods), we clearly see that these two substances are active against MDA-MB-231 breast cancer cells, with CAPE displaying $\mathrm{IC}_{50}$ values more than twice as low as CA.

The next stage was an analysis of CA and CAPE's influence on migration of MDA-MB-231 cells. This was measured by wound healing, which is the complex, dynamic process of movement and replacement of missing cells. Observation of live cells' motility is an effective method to measure the rate of migration into the space created by the original wound. The desired situation is when the wound closes as little as possible, so the gap area value over the area of the original wound remains as great as possible, preferably for a prolonged period; this means the examined agent inhibits the migration of the carcinoma cells.

The results of the wound healing assay are presented in Figure 5. In the control group, cell migration was very dynamic, achieving a value of $16 \%$ after only $8 \mathrm{~h}$. As seen, the wound's closure was practically complete, reaching a rate value of $1 \%$ after $16 \mathrm{~h}$. There was no evidence of the wound after $24 \mathrm{~h}$. Using a $50 \mu \mathrm{M}$ dose of CA, the motility of the MDA-MB-231 cells was inhibited. The rate increased to $30 \%$ after $8 \mathrm{~h}, 11 \%$ after $16 \mathrm{~h}$ and $6 \%$ after $24 \mathrm{~h}$. The wound closure was not complete following the CA treatment. Increasing the CA dose to $100 \mu \mathrm{M}$ resulted in better closure rates and therefore promoted migration inhibition of the MDA-MB-231 cells. The wound area value was $49 \%$ in relation to the original scratch after $8 \mathrm{~h}$. A value of $16 \%$ was achieved after $16 \mathrm{~h}$, and, finally, $9 \%$ after $24 \mathrm{~h}$. Inhibition of the cell migration showed a dose-dependent trend.

Using CAPE for wound healing resulted in deeper inhibition of cell migration when compared to CA. For a CAPE dose of $50 \mu \mathrm{M}$, the gap area factor was $66 \%$ for $8 \mathrm{~h}$. The gap remained at $50 \%$ at $16 \mathrm{~h}$ and achieved a value of $28 \%$ after $24 \mathrm{~h}$. Increasing the CAPE dose to $100 \mu \mathrm{M}$ displayed better results, as was expected. CAPE stopped the MDA-MB-231 cells from migrating at $75 \%$, after $8 \mathrm{~h}$. The size of the gap remained stable, with a value of $72 \%$ after $16 \mathrm{~h}$, to reach a minimal value of $68 \%$ after $24 \mathrm{~h}$. CA and CAPE both inhibited migration of MDA-MB-231 cells in a dose-dependent manner. The CAPE treatment displayed better results, particularly for the $100 \mu \mathrm{M}$ dose, where the motility of tested breast carcinoma cells was practically halted. 


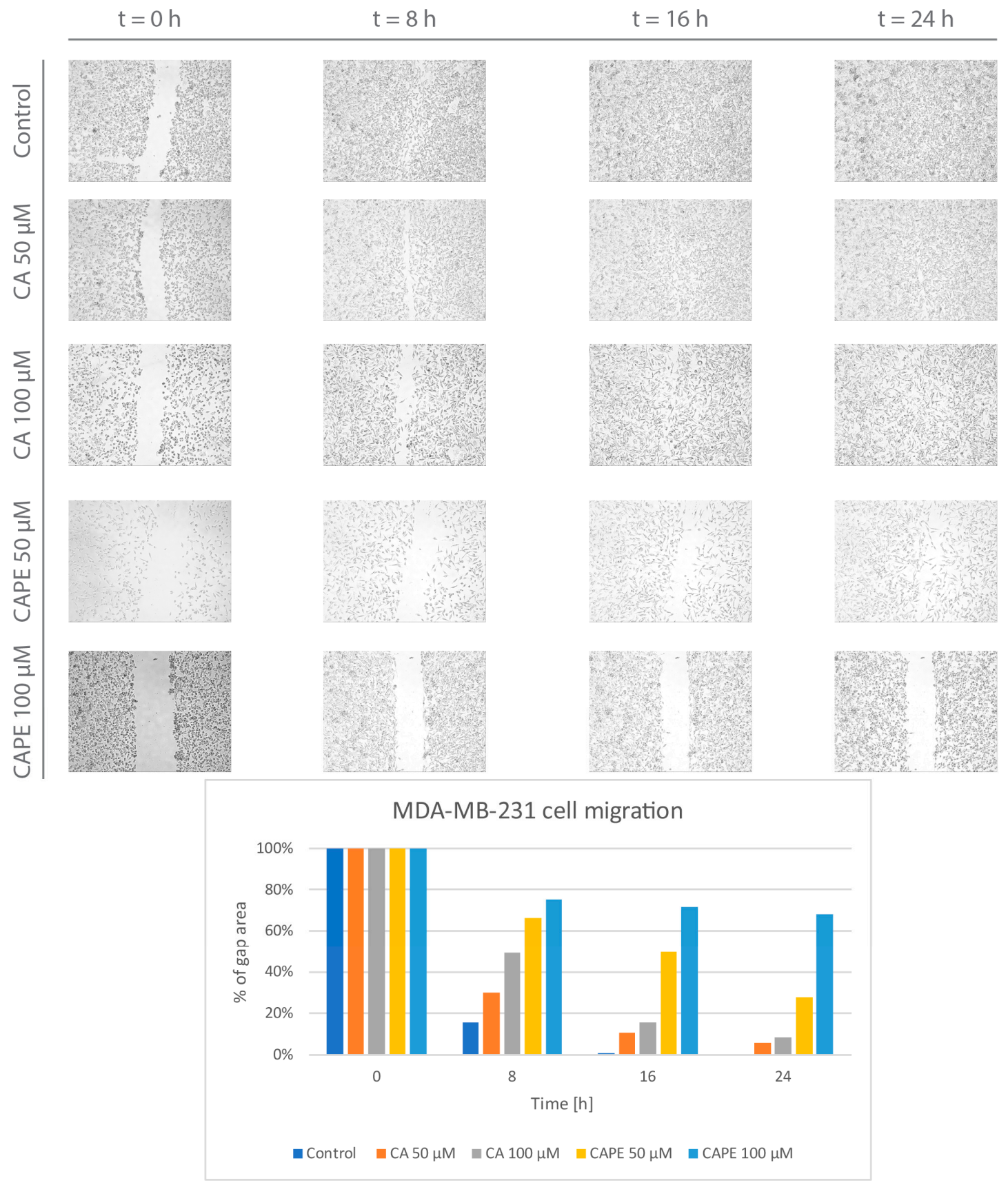

Figure 5. Caffeic acid (CA) and caffeic acid phenethyl ester (CAPE) at concentrations of $50 \mu \mathrm{M}$ and $100 \mu \mathrm{M}$ promote an inhibitory migration effect on MDA-MB-231 cells. There was a visible dose-dependent effect. The gap did not reach full closure for either agent. Comparison of these two substances shows CAPE has a greater influence on cell migration inhibition in MDA-MB-231 than CA. CAPE treatment with a dose of $100 \mu \mathrm{M}$ demonstrated that the wound area basically remained unchanged over time. CAPE created a 'barrier' that was practically impassable and impenetrable by the MDA-MB-231 cells. The cell migration factor was performed by monolayer gap closure migration assay and embedded by free ImageJ software. The results are presented as the gap area in relation to the area value of the initial scratch, after $8 \mathrm{~h}, 16 \mathrm{~h}$, and $24 \mathrm{~h}$ of observation.

\section{Discussion}

Research targeting finding new anticancer therapies is prompted by cancers' high mortality rate. Bioactive compounds have taken their place in the research arena as new, effective medicines $[59,60]$. 
Phytochemicals such as flavonoids, polyphenols, and phenolic acids are of great interest to scientists, due to their specific, active, anticancer effect on cancer cells [61,62].

Among patients diagnosed with breast cancer, complementary and targeted therapies using alternative natural substances are often employed. Between $63 \%$ to $80 \%$ of all breast cancer patients use at least one type of alternative medicine, while herbal or vitamin therapies are used by some $25 \%$ to $63 \%$ of the same patient group [63-67].

Simonetti et al. showed that CA is bioavailable and it may be correlated with the antioxidant potential of plasma, by intake of red wine [68].

The presence of the estrogen receptor is one of the priority classification factors of breast cancer cells $[18,69]$. For breast cancer, proliferation and survival of the cells is dependent on estrogen receptor signaling [22,70].

TNBC can be perfectly modeled using the MDA-MB-231 line because there are no estrogen receptors $\alpha$ and expression of estrogen receptor $\beta$ is minimal [71,72]. It was initially classified as a basal line of breast cancer cells because of the lack of ER and PR expression, as well as HER2 amplification. At present, it is considered to belong to the claudin-low molecular subtype because the line displays a down-regulation of claudin-3 and claudinin-4, as well as low expression of the Ki-67 proliferative marker and an enrichment of markers associated with an epithelial-mesenchymal transition and an expression of traits associated with breast cancer stem cells (CSC), such as CD44+/CD24-/low phenotype. The cells of this line are distinguished by invasive phenotype [72]. In a bone metastasis researches, the MDA-MD-231 cell line was widely used [73]. Also, the MDA-MB-231 cell subclones have been isolated. They displayed easy bone, brain, and lung metastases, after intraventricular injection into a mice organism. It allowed for the identification of genes and pathways that are potential mediators of metastasis to the specific sites when using this cell line [69,74-77].

For this research, we used MDA-MB-231 cell line as a model of TNBC. Considering the above, this comparative study of CA and CAPE substances, which occur naturally in propolis, shows much promise for breast cancer research.

The estrogenic effect of CAPE was not fully investigated, however; its ability to bind estrogen receptors has been previously shown. CAPE modulates the estrogen receptor selectively and it is more likely related to the estrogen receptor $\beta$ than $\alpha[22,69]$. This may indicate that the estrogen-related compounds act better on estrogen-positive neoplastic cells $[25,78]$.

Khoram et al. [79] showed that CAPE stimulated radiosensitivity in breast cancer cells. Clonogenicity was inhibited and radiation-induced DNA damage was maintained in two cell lines, particularly in T47D cells.

Chen et al. [28] and Lin et al. [80] observed that CAPE's anticancer activity was due to cell growth inhibition and a viability decline, both in a time and a dose-dependent manner. In another study, CAPE reduced the colony formation ability of PC-3 prostate cancer cells [26].

In an in vivo study, Wu et al. [27] showed CAPE's ability to reduce the volume of breast cancer tumors, respectively, by $40 \%$ and $60 \%$ for MDA-231 and MCF-7 xenografts. Interestingly, the lower dose of CAPE $(10 \mu \mathrm{M})$ was more effective to inhibit the growth of MDA-231 xenografts than $50 \mu \mathrm{M}$ for the MCF-7 xenografts.

In earlier research, we compared the in vitro cytotoxic activity of ethanol extract of propolis and CAPE against two cell lines, MDA-MB-231 and Hs578T, using MTT and lactate dehydrogenase (LDH) assays. $\mathrm{IC}_{50}$ values obtained for CAPE (both assays) were definitely lower than for ethanol extract of propolis [39].

Watabe et al. showed that CAPE inhibits nuclear factor NFKB. They also examined CAPE to confirm that death-inducing receptors clustered. They found that Fas death-inducing receptors were aggregated through a Fas-L independent mechanism in the MCF-7 cells. Consequently, it was shown that CAPE induced apoptosis. The aggregation of death receptors was executed through two pathways; FADD/caspase-8 and JNK/p38 [38]. 
Beauregard et al. tested CAPE and its 18 derivatives against breast cancer MCF-7 cells. Induction of caspase 3/7 resulted in apoptosis in five of eighteen CAPE-derivatives, which was even better than CAPE alone. Inhibition of NFKB was similar for all tested analogs and CAPE itself. They found that activation of the 553 pathway was realized by all CAPE derivatives [81].

Rosendahl et al. [82] tested caffeine and CA against breast cancer cells MCF-7, T47D, and MDA-MB-231. Their results showed that CA inhibited the proliferation of breast cancer cells, reducing the growth of breast cancer cells through modulating ER and IGFIR levels, thereby influencing downstream effectors and cell-cycle progression, but better CA activity in the MCF-7 cells (estrogen-positive) was observed. Their results displayed that CA suppressed the proliferation of breast cancer cells. They also tested an influence of coffee intake on a breast cancer disease. A higher coffee intake was correlated with a smaller invasion of primary tumors. On the other hand, it was reported by $\mathrm{Wu}$ [23] that CAPE inhibits MCF-7 and MDA-231 cells growth. In both cell lines, CAPE induced apoptosis and cell cycle arrest, and inhibited NF- $\mathrm{kB}$ as well as down-regulated the mdr-1 gene. VEGF formation was also suppressed by MDA-MB-231 cells. We can assume that activity of CA is closely related to the expression of estrogen, while CAPE acts independently of estrogen.

Our results showed that CAPE has a better cytotoxic effect than CA, which is in line with other research. However, our comparison of these two agents is novel, as it uses a triple cytotoxic assay.

Breast cancer metastasis is one of the primary reasons for its high mortality rate; therefore, migration and invasion research, as well as their mechanism, are part of the new era of breast cancer studies.

Wadhwa et al. used a free form of CAPE, as well as CAPE in a complex with gamma cyclodextrin $(\gamma \mathrm{CD})$ (equivalent doses), for cell viability studies of breast cancer lines MCF-7 and MDA-MB-231. They showed that CAPE displayed short-term toxicity, while CAPE- $\gamma$ CD complex caused permanent growth inhibition or apoptosis, which suggested that CAPE- $\gamma C D$ complex was characterized by a stronger effect. They also found that CAPE causes upregulation of p53 function by targeting mortalin-p53-interaction. The scratch and invasion studies on MCF-7 and MDA-MB-231 cells and their metastatic samples have shown that both CAPE- $\gamma$ CD complex and CAPE alone exhibit anti-migration activity [83].

Bonuccelli et al. showed that CAPE treatment significantly reduced wound closure (about 70\% vs control) on breast cancer MCF-7 cells. In the $24 \mathrm{~h}$ period, CAPE acted as a natural mitochondrial OXPHOS inhibitor, which preventively targeted stem-like cancer cells. They also suggested that CAPE blocks formation of the mammosphere [84].

Recent research is being conducted to find a mechanism of the breast cancer cells migration.

Interesting results were proposed by Buchegger et al. [85]. They suggested potential mechanism of migration of MDA-MB-231 cells. They expressed Reprimo (RPRM) ectopically in MDA-MB-231 cells. RPRM is located at $2 \mathrm{q} 23$ and encodes a highly glycosylated protein that shows four bands $(16,21,23$, and $40 \mathrm{kDa})$ found predominantly in the cytoplasm. They found that RPRM overexpression suppressed migration and invasion of MDA-MB-231 cells. Another study on a mechanism of the migration was done by Bhat et al. [86]. Growth-regulated oncogene $\alpha(\mathrm{GRO} \alpha)$ is a chemokine that plays a role not only in inflammation, but also in tumorigenesis. They found that MDA-MB-231 cells without GRO $\alpha$ exhibited a significant migration decrease and invasion properties reduction. Liu et al. [87] showed that CD74 is involved in breast carcinoma metastasis. CD74 protein is the invariant chain of major histocompatibility complex (MHC) class II. Their results showed that this factor was highly expressed in MDA-MB-231 cells; furthermore, a downregulation of CD74 inhibited both migration and invasion of MDA-MB-231 cells. Wang et al. [88] reported that TBC1D3 oncogene promotes the migration of breast cancer cells, and its interaction with calmodulin enhances the effects of TBC1D3.

CAPE is known as a specific inhibitor of activation of nuclear transcription factor NF- $\mathrm{kB}$ in breast cancer cells $[38,89]$. Also, Wang et al. [90] found that an activation of NF- $\mathrm{kB}$ is required for the cell migration and TBC1D3-induced expression of OLR1, an oxidized low-density lipoprotein receptor 1, 
also known as lectin-like oxidized low-density lipoprotein (oxLDL) receptor-1. Our results showed a motility inhibition of human breast cancer cells by CAPE. It appears that CAPE addition inhibited the ability of the oncogene TBC1D3 to stimulate OLR1 expression in MDA-MB-231 cells. The tumor cells migration might be induced by TBC1D3, therefore an inhibition of NF- $\mathrm{B}$ could result in the migration suppression thanks to CAPE addition.

CAPE influence on the migration of lung cancer A549 cells was tested by Shigeoka et al. They found that CAPE suppressed the motility promoted by TGF-beta-induced Akt phosphorylation [89].

Today, natural resources are being used more often. Also, a synthesis of analogues from natural remedies is proving to be an interesting source of substances that exhibit favorable activity for breast cancer treatment $[90,91]$.

In earlier studies, we investigated the effect of CA on wound scratch on human squamous cell carcinoma cell line SCC-25. For ethanol treatment, approximately 5\% of the wound was visible, while there was no closure if CA or a CA/ethanol mixture were used after $12 \mathrm{~h}$. Total or nearly complete closure occurred after a treatment with 50 and $100 \mathrm{mmol} / \mathrm{L}$ of ethanol after $30 \mathrm{~h}$, while with CA, a dose of $50 \mu \mathrm{M}$ significantly inhibited migration of the cancer cells, leaving from $30 \%$ to $40 \%$ of wound closure after $30 \mathrm{~h}$. The biggest gap (approx. 80\%) was observed for pure CA treatment with a dose of $50 \mu \mathrm{M}$ after $48 \mathrm{~h}$ [34].

We also compared the cytotoxic properties (by MTT) of CA and CAPE apoptosis induction and cell cycle arrest capabilities against MDA-MB-231 cells and found better activity of CAPE, with the same dosage and time of experiment [92].

Our novel comparative study confirms that CA and CAPE suspended migration rate of breast cancer MDA-MB-231 cells; however, much better results were obtained by the CAPE treatment.

\section{Conclusions}

In this limited in vitro study, we showed a comparison of CA and CAPE, two bioactive substances isolated from bee propolis. An XTT-NR-SRB assay and migration evaluation by wound healing assay were performed. We strongly believe, based on our results and other reports, that CA and CAPE can be used for chemoprevention. Nevertheless, more advanced studies are needed, particularly clinical trials. The mechanism of CA and CAPE's anticancer activity is becoming more well understood and documented; however, it remains a field in need of further investigation. Hopefully, this new approach of testing natural agents for breast cancer research will carefully explore the anti-cancer properties of all polyphenols. Our comparison of the effect of CA and CAPE on MDA-MB-231 cells clearly showed better results for CAPE-producing anticancer properties using the same dosages and experiment times.

Acknowledgments: This study was supported by a research grant from the Medical University of Silesia in Katowice, Poland, No. KNW 1-169/N/6/0.

Author Contributions: Agata Kabała-Dzik conceived the study idea, designed and performed the experiments, analyzed the data, and wrote the manuscript. Anna Rzepecka-Stojko carried out the experimental protocol; Robert Kubina performed the experiments and organized the data. Żaneta Jastrzebska-Stojko analyzed the data and made discussion research. Rafał Stojko consulted current treatments of breast cancer and analyzed the results; Robert Dariusz Wojtyczka organized the data and revised the manuscript. Jerzy Stojko contributed reagents and tools and critically revised the manuscript. All authors read and approved the final manuscript.

Conflicts of Interest: The authors declare no conflict of interest. The founding sponsor had no role in the design of the study; in the collection, analyses, or interpretation of data; in the writing of the manuscript, or in the decision to publish the results.

\section{References}

1. Rzepecka-Stojko, A.; Stojko, J.; Kurek-Gorecka, A.; Gorecki, M.; Kabala-Dzik, A.; Kubina, R.; Mozdzierz, A.; Buszman, E. Polyphenols from bee pollen: Structure, absorption, metabolism and biological activity. Molecules 2015, 20, 21732-21749. [CrossRef] [PubMed]

2. Rice-Evans, C.A.; Miller, N.J.; Paganga, G. Structure-Antioxidant activity relationships of flavonoids and phenolic acids. Free Radic. Biol. Med. 1996, 20, 933-956. [CrossRef] 
3. Iriti, M. Editorial: Introduction to polyphenols, plant chemicals for human health. Mini-Rev. Med. Chem. 2011, 11, 1183-1185. [PubMed]

4. Castaldo, S.; Capasso, F. Propolis, an old remedy used in modern medicine. Fitoterapia 2002, 73 (Suppl. 1), S1-S6. [CrossRef]

5. Popova, M.; Giannopoulou, E.; Skalicka-Wozniak, K.; Graikou, K.; Widelski, J.; Bankova, V.; Kalofonos, H.; Sivolapenko, G.; Gawel-Beben, K.; Antosiewicz, B.; et al. Characterization and biological evaluation of propolis from Poland. Molecules 2017, 22, 1159. [CrossRef] [PubMed]

6. Sforcin, J.M.; Bankova, V.; Kuropatnicki, A.K. Medical Benefits of Honeybee Products. Evid. Based Complement. Altern. Med. 2017, 2017, 2702106. [CrossRef] [PubMed]

7. Wojtyczka, R.D.; Dziedzic, A.; Idzik, D.; Kepa, M.; Kubina, R.; Kabala-Dzik, A.; Smolen-Dzirba, J.; Stojko, J.; Sajewicz, M.; Wasik, T.J. Susceptibility of Staphylococcus aureus clinical isolates to propolis extract alone or in combination with antimicrobial drugs. Molecules 2013, 18, 9623-9640. [CrossRef] [PubMed]

8. Dziedzic, A.; Kubina, R.; Wojtyczka, R.D.; Kabala-Dzik, A.; Tanasiewicz, M.; Morawiec, T. The antibacterial effect of ethanol extract of polish propolis on mutans streptococci and lactobacilli isolated from saliva. Evid. Based Complement. Altern. Med. 2013, 2013, 681891. [CrossRef] [PubMed]

9. Wang, P.; Liu, C.; Sanches, T.; Zhong, Y.; Liu, B.; Xiong, J.; Neamati, N.; Zhao, G. Design and synthesis of novel nitrogen-containing polyhydroxylated aromatics as HIV-1 integrase inhibitors from caffeic acid phenethyl ester. Bioorg. Med. Chem. Lett. 2009, 19, 4574-4578. [CrossRef] [PubMed]

10. Bufalo, M.C.; Bordon-Graciani, A.P.; Conti, B.J.; de Assis Golim, M.; Sforcin, J.M. The immunomodulatory effect of propolis on receptors expression, cytokine production and fungicidal activity of human monocytes. J. Pharm. Pharmacol. 2014, 66, 1497-1504. [CrossRef] [PubMed]

11. Jastrzebska-Stojko, Z.; Stojko, R.; Rzepecka-Stojko, A.; Kabala-Dzik, A.; Stojko, J. Biological activity of propolis-honey balm in the treatment of experimentally-evoked burn wounds. Molecules 2013, 18, 14397-14413. [CrossRef] [PubMed]

12. Kurek-Gorecka, A.; Rzepecka-Stojko, A.; Gorecki, M.; Stojko, J.; Sosada, M.; Swierczek-Zieba, G. Structure and antioxidant activity of polyphenols derived from propolis. Molecules 2013, 19, 78-101. [CrossRef] [PubMed]

13. Iriti, M.; Kubina, R.; Cochis, A.; Sorrentino, R.; Varoni, E.M.; Kabala-Dzik, A.; Azzimonti, B.; Dziedzic, A.; Rimondini, L.; Wojtyczka, R.D. Rutin, a quercetin glycoside, restores chemosensitivity in human breast cancer cells. Phytother. Res. 2017, 31, 1529-1539. [CrossRef] [PubMed]

14. Su, K.Y.; Hsieh, C.Y.; Chen, Y.W.; Chuang, C.T.; Chen, C.T.; Chen, Y.L. Taiwanese green propolis and propolin $\mathrm{G}$ protect the liver from the pathogenesis of fibrosis via eliminating TGF-beta-induced Smad2/3 phosphorylation. J. Agric. Food Chem. 2014. [CrossRef] [PubMed]

15. Chen, Y.J.; Shiao, M.S.; Hsu, M.L.; Tsai, T.H.; Wang, S.Y. Effect of caffeic acid phenethyl ester, an antioxidant from propolis, on inducing apoptosis in human leukemic HL-60 cells. J. Agric. Food Chem. 2001, 49, 5615-5619. [CrossRef] [PubMed]

16. Kustiawan, P.M.; Puthong, S.; Arung, E.T.; Chanchao, C. In vitro cytotoxicity of Indonesian stingless bee products against human cancer cell lines. Asian Pac. J. Trop Med. 2014, 4, 549-556. [CrossRef] [PubMed]

17. Xuan, H.; Li, Z.; Yan, H.; Sang, Q.; Wang, K.; He, Q.; Wang, Y.; Hu, F. Antitumor activity of Chinese propolis in human breast cancer MCF-7 and MDA-MB-231 cells. Evid. Based Complement. Altern. Med. 2014, 2014, 280120. [CrossRef] [PubMed]

18. Kamiya, T.; Nishihara, H.; Hara, H.; Adachi, T. Ethanol extract of Brazilian red propolis induces apoptosis in human breast cancer MCF-7 cells through endoplasmic reticulum stress. J. Agric. Food Chem. 2012, 60, 11065-11070. [CrossRef] [PubMed]

19. Yildirim, O.; Yilmaz, A.; Oz, O.; Vatansever, H.; Cinel, L.; Aslan, G.; Tamer, L.; Adiguzel, U.; Arpaci, R.; Kanik, A.; et al. Effect of caffeic acid phenethyl ester on treatment of experimentally induced methicillin-resistant Staphylococcus epidermidis endophthalmitis in a rabbit model. Cell Biochem. Funct. 2007, 25, 693-700. [CrossRef] [PubMed]

20. Cho, M.S.; Park, W.S.; Jung, W.K.; Qian, Z.J.; Lee, D.S.; Choi, J.S.; Lee, D.Y.; Park, S.G.; Seo, S.K.; Kim, H.J.; et al. Caffeic acid phenethyl ester promotes anti-inflammatory effects by inhibiting MAPK and NF-kappaB signaling in activated HMC-1 human mast cells. Pharm. Biol. 2014, 52, 926-932. [CrossRef] [PubMed] 
21. Altuntas, A.; Yilmaz, H.R.; Altuntas, A.; Uz, E.; Demir, M.; Gokcimen, A.; Aksu, O.; Bayram, D.S.; Sezer, M.T. Caffeic acid phenethyl ester protects against amphotericin B induced nephrotoxicity in rat model. Biomed. Res. Int. 2014, 2014, 702981. [CrossRef] [PubMed]

22. Zhou, K.; Li, X.; Du, Q.; Li, D.; Hu, M.; Yang, X.; Jiang, Q.; Li, Z. A CAPE analogue as novel antiplatelet agent efficiently inhibits collagen-induced platelet aggregation. Pharmazie 2014, 69, 615-620. [PubMed]

23. Wu, J.; Omene, C.; Karkoszka, J.; Bosland, M.; Eckard, J.; Klein, C.B.; Frenkel, K. Caffeic acid phenethyl ester (CAPE), derived from a honeybee product propolis, exhibits a diversity of anti-tumor effects in pre-clinical models of human breast cancer. Cancer Lett. 2011, 308, 43-53. [CrossRef] [PubMed]

24. Akyol, S.; Ozturk, G.; Ginis, Z.; Armutcu, F.; Yigitoglu, M.R.; Akyol, O. In vivo and in vitro antineoplastic actions of caffeic acid phenethyl ester (CAPE): Therapeutic perspectives. Nutr. Cancer 2013, 65, 515-526. [CrossRef] [PubMed]

25. Morin, P.; St-Coeur, P.D.; Doiron, J.A.; Cormier, M.; Poitras, J.J.; Surette, M.E.; Touaibia, M. Substituted caffeic and ferulic acid phenethyl esters: Synthesis, leukotrienes biosynthesis inhibition, and cytotoxic activity. Molecules 2017, 22, 124.

26. Borrelli, F.; Izzo, A.A.; Di Carlo, G.; Maffia, P.; Russo, A.; Maiello, F.M.; Capasso, F.; Mascolo, N. Effect of a propolis extract and caffeic acid phenethyl ester on formation of aberrant crypt foci and tumors in the rat colon. Fitoterapia 2002, 73 (Suppl. 1), S38-S43. [CrossRef]

27. Xiang, D.; Wang, D.; He, Y.; Xie, J.; Zhong, Z.; Li, Z.; Xie, J. Caffeic acid phenethyl ester induces growth arrest and apoptosis of colon cancer cells via the beta-catenin/T-cell factor signaling. Anti-Cancer Drug 2006, 17, 753-762. [CrossRef] [PubMed]

28. Chen, M.F.; Wu, C.T.; Chen, Y.J.; Keng, P.C.; Chen, W.C. Cell killing and radiosensitization by caffeic acid phenethyl ester (CAPE) in lung cancer cells. J. Radiat. Res. 2004, 45, 253-260. [CrossRef] [PubMed]

29. Kudugunti, S.K.; Vad, N.M.; Ekogbo, E.; Moridani, M.Y. Efficacy of caffeic acid phenethyl ester (CAPE) in skin B16-F0 melanoma tumor bearing C57BL/6 mice. Investig. New Drug 2011, 29, 52-62. [CrossRef] [PubMed]

30. Wu, C.S.; Chen, M.F.; Lee, I.L.; Tung, S.Y. Predictive role of nuclear factor-kappaB activity in gastric cancer: A promising adjuvant approach with caffeic acid phenethyl ester. J. Clin. Gastroenterol. 2007, 41, 894-900. [CrossRef] [PubMed]

31. Chen, M.J.; Chang, W.H.; Lin, C.C.; Liu, C.Y.; Wang, T.E.; Chu, C.H.; Shih, S.C.; Chen, Y.J. Caffeic acid phenethyl ester induces apoptosis of human pancreatic cancer cells involving caspase and mitochondrial dysfunction. Pancreatology 2008, 8, 566-576. [CrossRef] [PubMed]

32. Lee, K.W.; Kang, N.J.; Kim, J.H.; Lee, K.M.; Lee, D.E.; Hur, H.J.; Lee, H.J. Caffeic acid phenethyl ester inhibits invasion and expression of matrix metalloproteinase in SK-Hep1 human hepatocellular carcinoma cells by targeting nuclear factor kappa B. Genes Nutr. 2008, 2, 319-322. [CrossRef] [PubMed]

33. Huang, M.T.; Ma, W.; Yen, P.; Xie, J.G.; Han, J.; Frenkel, K.; Grunberger, D.; Conney, A.H. Inhibitory effects of caffeic acid phenethyl ester (CAPE) on 12-O-tetradecanoylphorbol-13-acetate-induced tumor promotion in mouse skin and the synthesis of DNA, RNA and protein in HeLa cells. Carcinogenesis 1996, 17, 761-765. [CrossRef] [PubMed]

34. Dziedzic, A.; Kubina, R.; Kabala-Dzik, A.; Wojtyczka, R.D.; Morawiec, T.; Buldak, R.J. Caffeic acid reduces the viability and migration rate of oral carcinoma cells (SCC-25) exposed to low concentrations of ethanol. Int. J. Mol. Sci. 2014, 15, 18725-18741. [CrossRef] [PubMed]

35. Dziedzic, A.; Kubina, R.; Kabala-Dzik, A.; Tanasiewicz, M. Induction of cell cycle arrest and apoptotic response of head and neck squamous carcinoma cells (Detroit 562) by caffeic acid and caffeic acid phenethyl ester derivative. Evid. Based Complement. Altern. Med. 2017, 2017, 6793456. [CrossRef] [PubMed]

36. Onori, P.; DeMorrow, S.; Gaudio, E.; Franchitto, A.; Mancinelli, R.; Venter, J.; Kopriva, S.; Ueno, Y.; Alvaro, D.; Savage, J.; et al. Caffeic acid phenethyl ester decreases cholangiocarcinoma growth by inhibition of NF-kappaB and induction of apoptosis. Int. J. Cancer 2009, 125, 565-576. [CrossRef] [PubMed]

37. Kuo, H.C.; Kuo, W.H.; Lee, Y.J.; Lin, W.L.; Chou, F.P.; Tseng, T.H. Inhibitory effect of caffeic acid phenethyl ester on the growth of C6 glioma cells in vitro and in vivo. Cancer Lett. 2006, 234, 199-208. [CrossRef] [PubMed]

38. Watabe, M.; Hishikawa, K.; Takayanagi, A.; Shimizu, N.; Nakaki, T. Caffeic acid phenethyl ester induces apoptosis by inhibition of NFkappaB and activation of Fas in human breast cancer MCF-7 cells. J. Biol. Chem. 2004, 279, 6017-6026. [CrossRef] [PubMed] 
39. Rzepecka-Stojko, A.; Kabała-Dzik, A.; Moździerz, A.; Kubina, R.; Wojtyczka, R.D.; Stojko, R.; Dziedzic, A.; Jastrzębska-Stojko, Ż.; Jurzak, M.; Buszman, E.; et al. Caffeic acid phenethyl ester and ethanol extract of propolis induce the complementary cytotoxic effect on triple-negative breast cancer cell lines. Molecules 2015, 20, 9242-9262. [CrossRef] [PubMed]

40. Liao, H.F.; Chen, Y.Y.; Liu, J.J.; Hsu, M.L.; Shieh, H.J.; Liao, H.J.; Shieh, C.J.; Shiao, M.S.; Chen, Y.J. Inhibitory effect of caffeic acid phenethyl ester on angiogenesis, tumor invasion, and metastasis. J. Agric. Food Chem. 2003, 51, 7907-7912. [CrossRef] [PubMed]

41. Wu, J.; Bukkapatnam, U.; Eckard, J.; Frenkel, K. Caffeic acid phenethyl ester (CAPE, a product of propolis) as an inhibitor of human breast cancer growth in a pre-clinical study and its effects on factors involved in cell cycle, angiogenesis, and drug resistance. In Proceedings of the AACR Annual Meeting, San Diego, CA, USA, 12-16 April 2008; Volume 68, p. 5710.

42. Jia, L.T.; Zhang, R.; Shen, L.; Yang, A.G. Regulators of carcinogenesis: Emerging roles beyond their primary functions. Cancer Lett. 2015, 357, 75-82. [CrossRef] [PubMed]

43. Carey, L.A. Directed therapy of subtypes of triple-negative breast cancer. Oncologist 2010, 15 (Suppl. 5), 49-56. [CrossRef] [PubMed]

44. Bauer, K.R.; Brown, M.; Cress, R.D.; Parise, C.A.; Caggiano, V. Descriptive analysis of estrogen receptor (ER)-negative, progesterone receptor (PR)-negative, and HER2-negative invasive breast cancer, the so-called triple-negative phenotype. Cancer 2007, 109, 1721-1728. [CrossRef] [PubMed]

45. Chacón, R.D.; Costanzo, M.V. Triple-negative breast cancer. Breat Cancer Res. 2010, 12 (Suppl. 2 ), S3. [CrossRef] [PubMed]

46. Foulkes, W.D.; Smith, I.E.; Reis-Filho, J.S. Triple-Negative Breast Cancer. N. Engl. J. Med. 2010, 363, 1938-1948. [CrossRef] [PubMed]

47. Hammond, M.E.; Hayes, D.F.; Dowsett, M.; Allred, D.C.; Hagerty, K.L.; Badve, S.; Fitzgibbons, P.L.; Francis, G.; Goldstein, N.S.; Hayes, M.; et al. American Society of Clinical Oncology/College of American Pathologists guideline recommendations for immunohistochemical testing of estrogen and progesterone receptors in breast cancer. J. Clin. Oncol. 2010, 28, 2784-2795. [CrossRef] [PubMed]

48. Pal, S.K.; Childs, B.H.; Pegram, M. Triple negative breast cancer: Unmet medical needs. Breast Cancer Res. Treat. 2011, 125, 627-636. [CrossRef] [PubMed]

49. Conlin, A.K.; Seidman, A.D. Taxanes in breast cancer: An update. Curr. Oncol. Rep. 2007, 9, 22-30. [CrossRef] [PubMed]

50. Jones, S.E. Metastatic breast cancer: The treatment challenge. Clin. Breast Cancer 2008, 8, 224-233. [CrossRef] [PubMed]

51. Schwartz, J.; Wong, S.T. Novel combinations for treating metastatic breast cancer: Improving the odds. Introduction. Am. J. Health Syst. Pharm. 2009, 66 (Suppl. 6), S1-S2. [CrossRef] [PubMed]

52. Longley, D.B.; Johnston, P.G. Molecular mechanisms of drug resistance. J. Pathol. 2005, 205, $275-292$. [CrossRef] [PubMed]

53. Mosmann, T. Rapid colorimetric assay for cellular growth and survival: Application to proliferation and cytotoxicity assays. J. Immunol. Methods 1983, 65, 55-63. [CrossRef]

54. Borenfreund, E.; Puerner, J. A simple quantitative procedure using monolayer cultures for cytotoxicity assays (HTD/NR90). J. Tissue Cult. Methods 1984, 9, 7-9. [CrossRef]

55. Skehan, P.; Storeng, R.; Scudiero, D.; Monks, A.; McMahon, J.; Vistica, D.; Warren, J.T.; Bokesch, H.; Kenney, S.; Boyd, M.R. New colorimetric cytotoxicity assay for anticancer-drug screening. J. Natl. Cancer Inst. 1990, 82, 1107-1112. [CrossRef] [PubMed]

56. Orellana, E.A.; Kasinski, A.L. Sulforhodamine B (SRB) assay in cell culture to investigate cell proliferation. Bio-protocol 2016, 6, E1984. [CrossRef] [PubMed]

57. Yarrow, J.C.; Perlman, Z.E.; Westwood, N.J.; Mitchison, T.J. A high-throughput cell migration assay using scratch wound healing, a comparison of image-based readout methods. BMC Biotechnol. 2004, 4, 21. [CrossRef] [PubMed]

58. Jonkman, J.E.; Cathcart, J.A.; Xu, F.; Bartolini, M.E.; Amon, J.E.; Stevens, K.M.; Colarusso, P. An introduction to the wound healing assay using live-cell microscopy. Cell. Adhes. Migr. 2014, 8, 440-451. [CrossRef] [PubMed] 
59. Mukhtar, E.; Adhami, V.M.; Khan, N.; Mukhtar, H. Apoptosis and autophagy induction as mechanism of cancer prevention by naturally occurring dietary agents. Curr. Drug Targets 2012, 13, 1831-1841. [CrossRef] [PubMed]

60. Beutler, J.A. Natural Products and Cancer Drug Discovery; Springer: New York, NY, USA, 2013; p. 244.

61. Mates, J.M.; Segura, J.A.; Alonso, F.J.; Marquez, J. Natural antioxidants: Therapeutic prospects for cancer and neurological diseases. Mini Rev. Med. Chem. 2009, 9, 1202-1214. [CrossRef] [PubMed]

62. Mates, J.M.; Segura, J.A.; Alonso, F.J.; Marquez, J. Anticancer antioxidant regulatory functions of phytochemicals. Curr. Med. Chem. 2011, 18, 2315-2338. [CrossRef] [PubMed]

63. DiGianni, L.M.; Garber, J.E.; Winer, E.P. Complementary and alternative medicine use among women with breast cancer. J. Clin. Oncol. 2002, 20 (Suppl. 18), S34-S38.

64. Crocetti, E.; Crotti, N.; Feltrin, A.; Ponton, P.; Geddes, M.; Buiatti, E. The use of complementary therapies by breast cancer patients attending conventional treatment. Eur. J. Cancer 1998, 34, 324-328. [CrossRef]

65. Sparber, A.; Bauer, L.; Curt, G.; Eisenberg, D.; Levin, T.; Parks, S.; Steinberg, S.M.; Wootton, J. Use of complementary medicine by adult patients participating in cancer clinical trials. Oncol. Nurs. Forum 2000, 27, 623-630. [PubMed]

66. Richardson, M.A.; Sanders, T.; Palmer, J.L.; Greisinger, A.; Singletary, S.E. Complementary/alternative medicine use in a comprehensive cancer center and the implications for oncology. J. Clin. Oncol. 2000, 18, 2505-2514. [CrossRef] [PubMed]

67. Morris, K.T.; Johnson, N.; Homer, L.; Walts, D. A comparison of complementary therapy use between breast cancer patients and patients with other primary tumor sites. Am. J. Surg. 2000, 179, 407-411. [CrossRef]

68. Simonetti, P.; Gardana, C.; Pietta, P. Plasma levels of caffeic acid and antioxidant status after red wine intake. J. Agric. Food Chem. 2001, 49, 5964-5968. [CrossRef] [PubMed]

69. Chavez, K.J.; Garimella, S.V.; Lipkowitz, S. Triple negative breast cancer cell lines: One tool in the search for better treatment of triple negative breast cancer. Breast Dis. 2010, 32, 35-48. [CrossRef] [PubMed]

70. Omene, C.; Kalac, M.; Wu, J.; Marchi, E.; Frenkel, K.; O'Connor, O.A. Propolis and its active component, caffeic acid phenethyl ester (CAPE), modulate breast cancer therapeutic targets via an epigenetically mediated mechanism of action. J. Cancer Ther. 2013, 5, 334-342.

71. Thomas, C.; Rajapaksa, G.; Nikolos, F.; Hao, R.; Katchy, A.; McCollum, C.W.; Bondesson, M.; Quinlan, P.; Thompson, A.; Krishnamurthy, S.; et al. ERbeta1 represses basal breast cancer epithelial to mesenchymal transition by destabilizing EGFR. Breast Cancer Res. 2012, 14, R148. [CrossRef] [PubMed]

72. Holliday, D.L.; Speirs, V. Choosing the right cell line for breast cancer research. Breast Cancer Res. 2011, 13, 215. [CrossRef] [PubMed]

73. Simmons, J.K.; Hildreth, B.E.; Supsavhad, W.; Elshafae, S.M.; Hassan, B.B.; Dirksen, W.P.; Toribio, R.E.; Rosol, T.J. Animal models of bone metastasis. Vet. Pathol. 2015, 52, 827-841. [CrossRef] [PubMed]

74. Bos, P.D.; Zhang, X.H.; Nadal, C.; Shu, W.; Gomis, R.R.; Nguyen, D.X.; Minn, A.J.; van de Vijver, M.J.; Gerald, W.L.; Foekens, J.A.; et al. Genes that mediate breast cancer metastatis to the brain. Nature 2009, 459, 1005-1009. [CrossRef] [PubMed]

75. Kang, Y.; Siegel, P.M.; Shu, W.; Drobnjak, M.; Kakonen, S.M.; Cordon-Cardo, C.; Guise, T.A.; Massagué, J. A multigenic program mediating breast cancer metastasis to bone. Cancer Cell 2003, 3, 537-549. [CrossRef]

76. Minn, A.J.; Gupta, G.P.; Siegel, P.M.; Bos, P.D.; Shu, W.; Giri, D.D.; Viale, A.; Olshen, A.B.; Gerald, W.L.; Massagué, J. Genes that mediate breast cancer metastasis to lung. Nature 2005, 436, 518-524. [CrossRef] [PubMed]

77. Minn, A.J.; Kang, Y.; Serganova, I.; Gupta, G.P.; Giri, D.D.; Doubrovin, M.; Ponomarev, V.; Gerald, W.L.; Blasberg, R.; Massagué, J. Distinct organ-specific metastatic potential of individual breast cancer cells and primary tumours. J. Clin. Investig. 2005, 115, 44-55. [CrossRef] [PubMed]

78. Jung, B.I.; Kim, M.S.; Kim, H.A.; Kim, D.; Yang, J.; Her, S.; Song, Y.S. Caffeic acid phenethyl ester, a component of beehive propolis, is a novel selective estrogen receptor modulator. Phytother. Res. 2010, 24, 295-300. [CrossRef] [PubMed]

79. Khoram, N.M.; Bigdeli, B.; Nikoofar, A.; Goliaei, B. Caffeic acid phenethyl ester increases radiosensitivity of estrogen receptor-positive and -negative breast cancer cells by prolonging radiation-induced DNA damage. J. Breast Cancer 2016, 19, 18-25. [CrossRef] [PubMed] 
80. Lin, Y.H.; Chiu, J.H.; Tseng, W.S.; Wong, T.T.; Chiou, S.H.; Yen, S.H. Antiproliferation and radiosensitization of caffeic acid phenethyl ester on human medulloblastoma cells. Cancer Chemother. Pharmacol. 2006, 57, 525-532. [CrossRef] [PubMed]

81. Beauregard, A.P.; Harquail, J.; Lassalle-Claux, G.; Belbraouet, M.; Jean-Francois, J.; Touaibia, M.; Robichaud, G.A. CAPE analogs induce growth arrest and apoptosis in breast cancer cells. Molecules 2015, 20, 12576-12589. [CrossRef] [PubMed]

82. Rosendahl, A.H.; Perks, C.M.; Zeng, L.; Markkula, A.; Simonsson, M.; Rose, C.; Ingvar, C.; Holly, J.M.; Jernstrom, H. Caffeine and caffeic acid inhibit growth and modify estrogen receptor and insulin-like growth factor i receptor levels in human breast cancer. Clin. Cancer Res. 2015, 21, 1877-1887. [CrossRef] [PubMed]

83. Wadhwa, R.; Nigam, N.; Bhargava, P.; Dhanjal, J.K.; Goyal, S.; Grover, A.; Sundar, D.; Ishida, Y.; Terao, K.; Kaul, S.C. Molecular characterization and enhancement of anticancer activity of caffeic acid phenethyl ester by gamma cyclodextrin. J. Cancer 2016, 7, 1755-1771. [CrossRef] [PubMed]

84. Bonuccelli, G.; De Francesco, E.M.; de Boer, R.; Tanowitz, H.B.; Lisanti, M.P. NADH autofluorescence, a new metabolic biomarker for cancer stem cells: Identification of vitamin C and CAPE as natural products targeting "stemness". Oncotarget 2017, 8, 20667-20678. [CrossRef] [PubMed]

85. Buchegger, K.; Ili, C.; Riquelme, I.; Letelier, P.; Corvalán, A.H.; Brebi, P.; Huang, T.H.; Roa, J.C. Reprimo as a modulator of cell migration and invasion in the MDA-MB-231 breast cancer cell line. Biol. Res. 2016, 49. [CrossRef] [PubMed]

86. Bhat, K.; Sarkissyan, M.; Wu, Y.; Vadgama, J.V. GRO $\alpha$ overexpression drives cell migration and invasion in triple negative breast cancer cells. Oncol. Rep. 2017, 38, 21-30. [CrossRef] [PubMed]

87. Liu, Z.; Chu, S.; Yao, S.; Li, Y.; Fan, S.; Sun, X.; Su, L.; Liu, X. CD74 interacts with CD44 and enhances tumorigenesis and metastasis via RHOA-mediated cofilin phosphorylation in human breast cancer cells. Oncotarget 2016, 7, 68303-68313. [CrossRef] [PubMed]

88. Wang, B.; Zhao, H.; Zhao, L.; Zhang, Y.; Wan, Q.; Shen, Y.; Bu, X.; Wan, M.; Shen, C. Up-regulation of OLR1 expression by TBC1D3 through activation of TNF $\alpha / \mathrm{NF}-\mathrm{kB}$ pathway promotes the migration of human breast cancer cells. Cancer Lett. 2017, 408, 60-70. [CrossRef] [PubMed]

89. Shigeoka, Y.; Igishi, T.; Matsumoto, S.; Nakanishi, H.; Kodani, M.; Yasuda, K.; Hitsuda, Y.; Shimizu, E. Sulindac sulfide and caffeic acid phenethyl ester suppress the motility of lung adenocarcinoma cells promoted by transforming growth factor- $\beta$ through Akt inhibition. J. Cancer Res. Clin. Oncol. 2004, 130, 146-152. [CrossRef] [PubMed]

90. Natarajan, K.; Singh, S.; Burke, T.R.; Grunberger, D.; Aggarwal, B.B. Caffeic acid phenethyl ester is a potent and specific inhibitor of activation of nuclear transcription factor NF-kappa B. Proc. Natl. Acad. Sci. USA 1996, 93, 9090-9095. [CrossRef] [PubMed]

91. Pidugu, V.R.; Yarla, N.; Bishayee, A.; Kalle, A.M.; Satya, A.K. Novel histone deacetylase 8-selective inhibitor 1,3,4-oxadiazole-alanine hybrid induces apoptosis in breast cancer cells. Apoptosis 2017. [CrossRef] [PubMed]

92. Kabała-Dzik, A.; Rzepecka-Stojko, A.; Kubina, R.; Jastrzębska-Stojko, Ż.; Stojko, R.; Wojtyczka, R.D.; Stojko, J. Comparison of two components of propolis: Caffeic acid (CA) and caffeic acid phenethyl ester (CAPE) induce apoptosis and cell cycle arrest of breast cancer cells MDA-MB-231. Molecules 2017, 22, 1554. [CrossRef] [PubMed]

(C) 2017 by the authors. Licensee MDPI, Basel, Switzerland. This article is an open access article distributed under the terms and conditions of the Creative Commons Attribution (CC BY) license (http://creativecommons.org/licenses/by/4.0/). 